\title{
Sodium Monofluoroacetate (1080): Relation of Its Use to Predation on Livestock in West- ern National Forests, 1960-78.
}

\author{
GREGORY W. LYNCH AND ROGER D. NASS
}

\begin{abstract}
Concern over certain animal damage control methods used by the U.S. Fish and Wildlife Service (USFWS), primarily the predacide Compound 1080, prompted a Presidential Order in 1972 banning the use of toxicants on public lands. This continuing ban of 1080 use has been reinforced by the recent policy address issued by the Secretary of the Interior. Following the initial ban, greater emphasis was placed on aerial hunting of coyotes for prevention and correction of damage to sheep and goats. Aerial hunting is expensive, however, and has only limited application in timbered, mountainous areas of many national forests. In the period since toxicants were banned, number of grazing livestock reported as lost to predation on western national forests has increased. Numbers of toxic bait stations (1080) used throughout the West, from 1960 until the 1972 ban, showed a strong inverse relationship with numbers of livestock reported lost to predation on national forests during these same years.
\end{abstract}

Use of predacides in the Animal Damage Control (ADC) program of the U.S. Fish and Wildlife Service (USFWS) has often been criticized because efficacy and safety data were limited or lacking. The most frequently criticized predacide is Sodium Monofluoroacetate (1080). Although the use of 1080 had been declining since at least the early 1960's, an Executive Order issued by President Nixon in 1972 immediately stopped further use of this and other predacides on public lands. Reinforcement of this ban on 1080 use and research was recently accomplished by an ADC Policy Statement issued by the Secretary of the Interior.

One result of the 1972 ban was the increased use of aircraft for predator control. If predacides are restricted from use indefinitely, aerial control provides the best economic alternative (Gum ct al. 1978). Cain et al. (1972) rated aerial hunting as "very good" in effectiveness for problem solving, safety, and lack of adverse environmental impact. Also, a telephone survey by Arthur et al. (1977) showed that aerial hunting is more acceptable to the general public than a re the slow-acting predacides. Aerial hunting is species selective and may often be selective for the depredating individual.

Evans and Pearson (1977) showed that the reported number of coyotes taken by ADC personnel generally rose during 1972-76 and that the percentage of these animals taken from aircraft greatly increased (Fig. 1). Most coyotes taken earlier with predacides were not recovered; consequently, the increase in numbers of coyotes reported taken in the ADC program since 1972 is probably a reflection of increased use of methods that lead to the recovery of animals, rather than an increase in numbers of animals killed.

Though aircraft may be an effective (albeit expensive) replacement for predacides in certain high-country meadow grazing areas,

\footnotetext{
Authors are biologist and project leader, respectively, Denver Wildlife Research Center, U.S. Fish and Wildlife Service, stationed in Twin Falls, Idaho 83301, Box 593. Lynch's current address is U.S. Forest Service, Box 338, Afton, Wyoming 83110.

Manuscript received October 15, 1979.
}

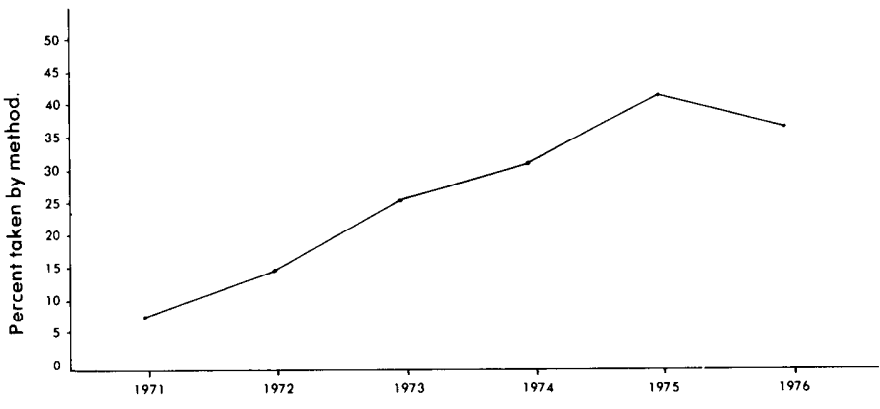

Fig. 1. Percentage of coyotes taken by $A D C$ personnel using aircraft (from Evans and Pearson 1977).

their effectiveness is sharply reduced in timbered, mountainous areas that make up a significant portion of the national forests. Consequently, even the increase in the aerial damage control since the 1972 predacide ban has not reduced, or even held constant, the losses of sheep on national forests. On the contrary, losses may have increased because 1080, which was frequently used in mountainous regions, was not replaced with an equally effective control measure in these areas. Comparison of expanded aerial control, number of 1080 bait stations used in the West, and the reported loss of sheep and goats to predation on the Forest Service lands is shown in Figure 2.

\section{Methods and Discussion}

Sheep and goat losses were tabulated from 1960 through 1978 to determine whether significant differences occurred after the 1972 predacide ban. Information available from the U.S. Forest Service is more detailed than that from any other source for comparing losses of livestock (goats, as well as sheep, are included in the reported number of a nimals grazed on the national forests, but the number of goats is so small that it can be ignored in calculations). The animals are counted when they are released onto the forest land each summer, and again when they are removed in the fall. The difference in the two counts is the number of animals lost to predation, weather, toxic plants, and other causes.

Wagner (1972) reported the Forest Service estimated levels of predator losses during the summer grazing season on the national forests ranged between 0.4 and 1.5 percent. Even while the use of 1080 was decreasing during 1960-72, the number of sheep lost to predators on the forests in the West was increasing (Table 1). These increasing losses occurred during an almost steady reduction in the numbers of sheep being grazed. Also, since grazing seasons on the forested areas are usually short, these losses of up to 1.5 percent were concentrated in time. Grazing time varied in 1972 from 0.7 to more than 11 months but averaged only 2.5 months in 68 national forests in the 17 western States (Pearson 1972). Losses suffered 


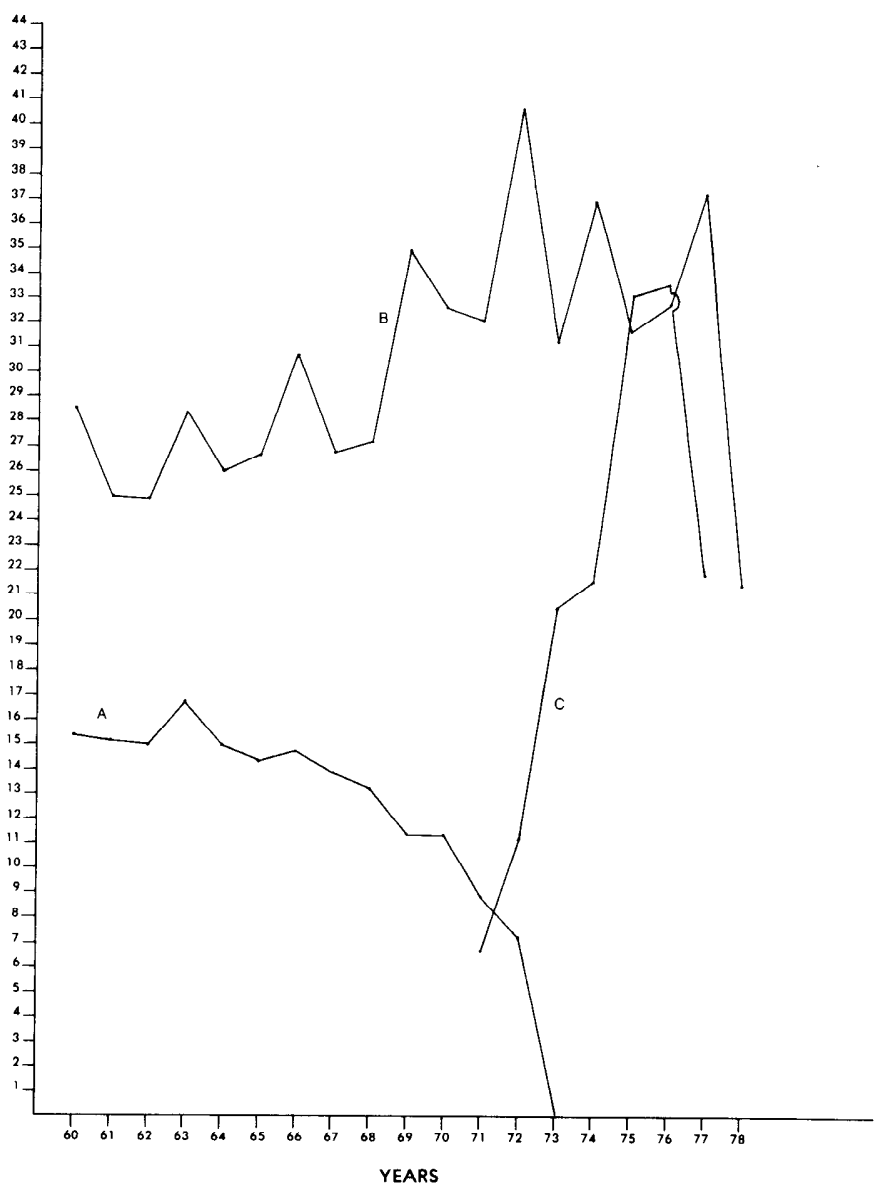

Fig. 2. Relationships among (A), the number of 1080 bait stations placed throughout the West (from Cain et al. 1972, and Orvis Gustad, Joe Packham, and George Rost, senior staff specialists in Regions 6, 1, and 2, respectively, USFWS, personal communication), (B), the number of sheep and goats reported lost to predators on the national forests (from Gee et al. 1977, and Jerry Austin, computer specialist, U.S. Forest Service, Washington, D.C., personal communication), and (C), the number of coyotes taken by ADC personnel with aircraft (from Evans and Pearson 1977). during the summer grazing on the forests are in addition to the heavy losses that occur during and immediately after the lambing season in late winter and early spring (Gee et al. 1977)

Another study outlining losses reported by livestock raisers to Forest Service officials showed that during 1956-71 the loss rate to predators never exceeded 1.9 percent (Gee et al. 1977). This loss rate essentially agrees with that reported by Wagner (1972). From 1972 through 1978, after the predacide ban, the reported losses from the national forests were never less than 1.7 percent and ranged up to 2.5 percent.

Lambs grazed on the national forests are nearing market size and represent a maximum investment for the rancher, in both time and money. These animals have survived the more critical earlyage period when most losses occur. Obviously, predation losses of lambs during this pcriod have a greater potential economic impact on the livestock operation than do the early-season losses.

The Forest Service data, reported as the number of animals grazed, includes only those over 6 months old. However, the number of animals reported lost to predation includes all animals, and most of these are lambs (less than 6 months old) on the summer range. A halving of the percentage of animals officially reported lost to predation may more accurately reflect the losses incurred during the summer grazing season. Partly offsetting this reporting difference is the possibility that many losses reported as "unknown cause" are the result of predation.

A linear regression was calculated on the number of 1080 bait stations placed throughout the West $(\mathrm{X})$ and the percentage of sheep reported lost to predation on the national forests (Y) in U.S. Forest Service Regions 1 through 6, for the 13 years (1960-72) immediately preceeding the predacide ban (Fig. 3). The coefficient of determination $\left(r^{2}\right)$ in this test is 0.86 . While the number of 1080 bait stations decreased, the percentage of sheep reported lost to predation on national forests increased.

Some of the initial reports may, in part, reflect dissatisfaction with the predacide ban. The last of the 1080 bait stations were removed in the spring of 1972 and the effect of the baiting should have lasted through the summer grazing season. However, the reported losses in 1972 were almost $27 \%$ higher than those in 1971. Even discounting this possible one-time emotional reaction, the annual percentage losses reported in 5 of the 6 years from 1972 to 1977 were greater than the highest reported beforc 1972. In 1978, a year that saw a much lower level of predation than the 6 previous years, the percentage of a nimals reported lost to predators was still

Table 1. Total number of 1080 bait stations, sheep and goats grazed, and losses attributed to predation on national forests, Regions 1-6, $1960-78$.

\begin{tabular}{|c|c|c|c|c|}
\hline \multirow[b]{2}{*}{ Year } & \multirow[b]{2}{*}{ Number of 1080 stations $^{1}$} & \multirow{2}{*}{$\begin{array}{l}\text { Number of sheep } \\
\text { and goats grazed }\end{array}$} & \multicolumn{2}{|c|}{ Sheep and goats reported lost to predation } \\
\hline & & & Number $^{2}$ & Percent of total animals \\
\hline 1960 & 15,349 & $2,531,000$ & 28,500 & 1.1 \\
\hline 1961 & 15,173 & $2,436,000$ & 25,000 & 1.0 \\
\hline 1962 & 15,079 & $2,334,000$ & 24,900 & 1.1 \\
\hline 1963 & 16,692 & $2,231,000$ & 28,400 & 1.3 \\
\hline 1964 & 15,017 & $2,158,000$ & 26,100 & 1.2 \\
\hline 1965 & 14,417 & $2,025,000$ & 26,700 & 1.3 \\
\hline 1966 & 14,665 & $2,027,000$ & 30,700 & 1.5 \\
\hline 1967 & 13,930 & $1,941,000$ & 26,800 & 1.4 \\
\hline 1968 & 13,260 & $1,879,000$ & 27,200 & 1.4 \\
\hline 1969 & 11,423 & $1,828,000$ & 35,000 & 1.9 \\
\hline 1970 & 11,373 & $1,741,000$ & 32,600 & 1.9 \\
\hline 1971 & 8,914 & $1,696,000$ & 32,100 & 1.9 \\
\hline 1972 & 7,289 & $1,652,000$ & 40,700 & 2.5 \\
\hline 1973 & 0 & $1,598,000$ & 31,300 & 2.0 \\
\hline 1974 & 0 & $1,470,000$ & 37,000 & 2.5 \\
\hline 1975 & 0 & $1,549,000$ & 31,800 & 2.1 \\
\hline 1976 & 0 & $1,749,777$ & 32,879 & 1.9 \\
\hline 1977 & 0 & $1,472,561$ & 37,442 & 2.5 \\
\hline 1978 & 0 & $1,283,672$ & 21,457 & 1.7 \\
\hline
\end{tabular}

IInformation for 1960-70 is Cain et al. (1972). Data from 1971 and 1972 comes from Orvis Gustad, Joe Packham, and George Rost, senior ADC staff specialists, USFWS Regions 6, 1, and 2, respectively, personal communications.

${ }^{2}$ Data for 196075 are from Gee et al. (1977) and those from 1976-78 are from Jerry Austin, computer specialist, U.S. Forest Service, Washington, D.C., personal communication. 


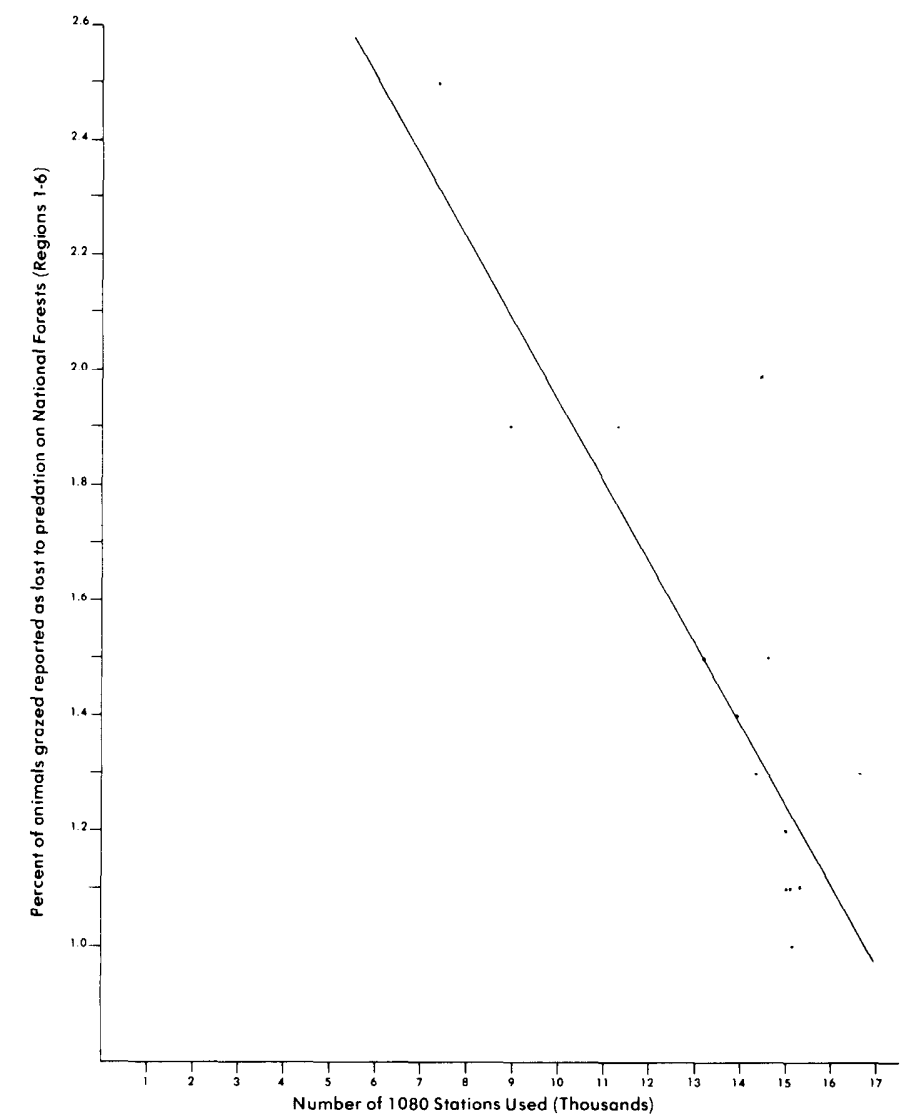

Fig. 3. Number of 1080 bait stations used (thousands) in relation to reported losses of sheep and goats to predation on western national forests, $1960-72\left(r^{2}=-0.86\right)$. greater than in all but 3 years from 1960-71.

Concentration of effort in the ADC program was redirected in favor of aerial hunting after the ban of predacide use on public lands. Although the percentage of predators taken by ADC personnel using aircraft has increased, most ranchers believe that better protection of livestock was achieved with predacides. A comparison of reported losses before and after the predacide ban adds wcight to this belief. Although other factors such as high fur prices may be affecting losses on national forests, there was an inverse relationship between the number of bait stations used and livestock losses.

\section{Literature Cited}

Arthur, L.M., R.L. Gum, E.H. Carpenter, and W.W. Shaw. 1977. Predator control: The public viewpoint. Trans. N. Amer. Wildl. Conf. 42:137-145.

Cain, S.A., J.A. Kadlec, D.L. Allen, R.A. Cooley, M.H. Hornocker, A.S. Leopold, and F.H. Wagner. 1972. Predator control-1971. Report to the Council on Environmental Quality and the Department of the Interior by the Advisory Committee on Predator Control. Ann Arbor: Univ. Michigan Press. 207 p.

Evans, G.D., and E.W. Pearson. 1977. Coyotes harvested and methods used in the cooperative federal animal damage control program in 16 western states, 1971-76. Suppl. Rep., Denver Wildl. Res. Center, U.S. Fish Wildl. Serv., Work Unit 1230-930-45-1. 10 p.

Gee, C.K., R.S. Magleby, W.R. Bailey, R.L. Gum, and L.M. Arthur. 1977. Sheep and lamb losses to predators and other causes in the western United States. AER-369, U.S. Dep. Agr., Econ. Res. Serv. 41 p.

Gum, R.L., L.M. Arthur, and R.S. Magleby. 1978. Coyote control: A simulation evaluation of alternative strategies. AER-408, U.S. Dep. Agr., Econ. Stat. Coop. Serv. 49 p.

Pearson, E.W. 1972. Current grazing of domestic sheep in national forests of the western United States. Suppl. Annu. Prog. Rep., Denver Wildl. Res. Center, U.S. Fish Wildl. Serv. 11 p.

Wagner, F.H. 1972. Coyotes and sheep. Some thoughts on ecology, economics, and ethics. 44th Honor Lecture, Fac. Ass., Utah State Univ., Logan. 59 p. 